\title{
Dexamethasone Administration to Newborn Mice Alters Mucosal and Muscular Morphology in the Ileum and Modulates IGF-I Localization
}

\author{
PHILLIP V. GORDON, WAYNE A. PRICE, AND ALAN D. STILES \\ Division of Neonatal-Perinatal Medicine, Department of Pediatrics, University of North Carolina at \\ Chapel Hill, Chapel Hill, North Carolina, U.S.A.
}

\begin{abstract}
Glucocorticoid exposure accelerates the maturation of small bowel mucosa. We hypothesized that IGF-I, a mitogen and differentiating peptide expressed in small bowel, mediates steroid-induced change within the developing ileum. To investigate this possibility, we intraperitoneally administered $1 \mu \mathrm{g} / \mathrm{gm} / \mathrm{d}$ of dexamethasone (DEX) or equal volumes of saline to litter-mate newborn mice. The animals were killed on d 1-3 of life and their ileums were harvested and prepared for microscopy. Tissue sections of ileum were examined for morphologic analyses, mucin staining, immunolocalization of IGF-I and -II, proliferating cell nuclear antigen (PCNA), terminal deoxynucleotidyl transferase-mediated dUTP nick end labeling (TUNEL), and in situ hybridization for IGF-I transcripts. Morphologic comparisons showed increases in goblet cell number, total cell number, and TUNEL-positive cells within the mucosa of DEX-treated animals. In contrast, the number of smooth muscle nuclei per cross-section was unchanged with DEX treatment despite a reduction in the number of PCNA-positive nuclei and an in-
\end{abstract}

\section{ABSTRACT}

creased bowel circumference. These findings suggest the muscularis stretches to accommodate increasing bowel diameter. IGF-I peptide was localized to the mesenchyme of all control animals. After $48 \mathrm{~h}$ of DEX treatment, IGF-I was detected in the epithelia whereas mesenchymal IGF-I localization appeared diminished. In situ hybridization analyses for IGF-I transcripts showed no differences in localization between the groups. We conclude that DEX administration differentially affects adjacent tissues in the newborn ileum and that the associated changes in IGF-I localization are consistent with its participation in this process. (Pediatr Res 49: 93-100, 2001)
DEX, dexamethasone;
Abbreviations:
PCNA, proliferating cell nuclear antigen;
TUNEL, terminal deoxynucleotide transferase-mediated dUTP nick end labeling

The fetal small bowel undergoes rapid maturation during the latter third of gestation by increasing villus length, mucosal thickness, goblet cell number, lumen diameter, and smooth muscle thickness. Cell proliferation, differentiation, and turnover must be coordinated by local growth factors for these changes to occur. The IGFs, with their known actions on cell proliferation, cell differentiation, cell motility, matrix production, and cell survival are logical candidates for participation in this process.

There are two forms of IGF. IGF-II is abundant in fetal tissue but rapidly wanes around the time of birth and is increasingly difficult to detect thereafter. IGF-I has been shown to be important for both growth and repair within developing and mature bowel models (1-3). For example, transgenic mice

Received April 6, 2000; accepted August 16, 2000

Correspondence: Wayne A. Price, M.D., Division of Neonatal-Perinatal Medicine CB\#7596, Department of Pediatrics, University of North Carolina at Chapel Hill, Chapel Hill, NC 27599-7596, U.S.A.

This work was supported by HL19171-18 SCOR (A.D.S.) from the National Institutes of Health. that overexpress IGF-I have longer small bowel length and increased mucosal mass when compared with controls. Likewise, i.v. IGF-I has been shown to rescue mucosal and villus atrophy in mature rodents receiving prolonged parental nutrition. Finally, IGF-I has been demonstrated to be a potent promoter of mucosal growth after bowel resection. Collectively, these findings suggest a central role for IGF-I in growthrelated phenomena of the bowel mucosa.

Glucocorticoids also affect the growth and differentiation of the bowel mucosa. Examples of this include glucocorticoidinduced expression of digestive enzymes, glucocorticoid increased goblet cell numbers, and glucocorticoid-induced thickening of the mucosa (4-8). Administration of glucocorticoids also has been associated with a decreased incidence of necrotizing enterocolitis in premature infants and rat pups $(9,10)$. Taken together, these findings suggest that steroids can induce precocious maturation of the bowel mucosa.

Recent clinical reports have also associated short courses of DEX in premature newborns with spontaneous perforation of the small bowel $(11,12)$. Review of the pathologic specimens 
from the patients in one of these reports revealed foci of degeneration within the circumferential smooth muscle in all cases examined (11). At the same time, examination of the mucosa within those specimens revealed healthy mucosa. This would suggest that glucocorticoid exposure results in asynchronous development between the mucosa and the muscle, rather than global maturation of the small bowel.

We hypothesized that glucocorticoids affect the morphology of the mucosa and the muscularis of the developing ileum differently and that these differences are mediated in part through the IGF system. To examine this hypothesis, we administered DEX or vehicle to newborn mice and examined ileum from each group for morphology, evidence of cell proliferation and apoptosis, and tissue localization of IGF-I and -II proteins and transcripts.

\section{MATERIALS AND METHODS}

Dexamethasone administration and tissue collection. The animal protocols in this study were reviewed and approved by the institutional animal care and use committee at the University of North Carolina. Newborn C57 litter-mate mice received daily i.p. injections of DEX $(1 \mu \mathrm{g} / \mathrm{gm})$ or saline beginning on the day of birth and repeated every $24 \mathrm{~h}$ for up to three doses. This dexamethasone dose and length of therapy approximates that used in a recent clinical trial where $17 \%$ of DEX-treated infants developed focal small bowel perforation (12). We chose to use intraperitoneal injections, rather than s.c. or intramuscular injections, because this best approximated i.v. delivery, which was not feasible in this animal model.

Three out of 10 original litters were discarded because of poor maternal behavior and/or poor lactation at the 24-h time point. From the remaining seven litters, at least four pups were killed for each treatment group at the 24- and 48-h time points to allow examination of morphologic changes over time. Up to nine pups were killed for each treatment group at the 72-h time point to provide sufficient sample size for statistical comparison. The ileum was removed, fixed in $10 \%$ buffered formalin (Fisher Scientific, Pittsburgh, PA, U.S.A.), and embedded in paraffin.

Morphologic examination of ileum. Sections $(4 \mu \mathrm{M})$ were stained with hematoxylin and eosin or alcian blue and imaged with an Olympus microscope. Digitized images were obtained using a Spot Jr. camera (Diagnostics Inc., Sterling Heights, MI, U.S.A.). The circumference of the surrounding smooth muscle was calculated from lumen diameter (diameter $\times \Pi=$ circumference). Photomicrographs of $10 \times$ objective magnification of each of the hematoxylin and eosin-stained sections were analyzed by drawing a line through the center of the lumen such that it bisected the section at the closest possible margins to minimize artifact from oblique-angle sections. The diameter was then measured as the distance between the internal margins of the circumferential smooth muscle bisected by that line.

To determine the number of smooth muscle nuclei in the circumferential smooth muscle, $20 \times$ digital images for each section were printed and manually counted. Smooth muscle cell numbers were generated by counting the all the smooth muscle nuclei within the muscularis externa of one quarter of the section. Total smooth muscle nuclei per cross-section were then calculated by multiplying by four.

The number of goblet cells per cross-section was determined using photomicrographs of $10 \times$ magnification of Alcian bluestained sections of ileum. The total number of mucin-positive cells was determined by manually counting all Alcian-stained cells in a quarter of each section and multiplying this number by four. The same approach was used to determination the number of cell nuclei with PCNA immunostaining and the number of TUNEL-positive cells.

In situ hybridization. In situ hybridization was performed as previously described with some modification (13). Sections from DEX and control mice were paired and processed on the same slide for the purpose of comparison. Sections were deparaffinized in xylene, then hydrated in decreasing ethanol concentrations to distilled water, digested in proteinase $\mathrm{K}$ (10 $\mathrm{mg} / \mathrm{mL}$ in $100 \mathrm{mM}$ Tris-HCl, $\mathrm{pH}$ 8.0; Boehringer Mannheim Corp., Indianapolis, IN, U.S.A.) for $15 \mathrm{~min}$ at $37^{\circ} \mathrm{C}$, then dehydrated in increasing ethanol concentrations and air dried before hybridization. Hybridization solution $(50 \%$ deionized formamide, $0.25 \mathrm{mg} / \mathrm{mL}$ yeast transfer RNA in $4 \times$ SSC [ $20 \times$ $\mathrm{SSC}=3 \mathrm{M} \mathrm{NaCl}, 0.3 \mathrm{M}$ sodium citrate, $\mathrm{pH} 6.0]$, $5 \mathrm{ng}$ FITC-conjugated UTP-labeled probe/section) was applied to each section and covered with a glass coverslip. A sense strand RNA probe for IGF-I was prepared as previously described (14). Sections were incubated in a humidified chamber at $60^{\circ} \mathrm{C}$ for 16-18 h, coverslips were then removed in $1 \times \mathrm{SSC}$, and sections washed in $1 \times \mathrm{SSC}$ for $60 \mathrm{~min}$ at $68^{\circ} \mathrm{C}$. Slides were washed four times at $60^{\circ} \mathrm{C}$ in $1 \times \mathrm{SSC}$, then twice in Buffer 1 (150 mM NaCl, $100 \mathrm{mM}$ Tris-HCl, pH 7.5). Sections were then soaked in Buffer 1 containing 1\% BSA (Boehringer Mannheim Corp.) for $30 \mathrm{~min}$ at $25^{\circ} \mathrm{C}$. Anti-FITC-horse radish peroxidase (HRP) $(1.5 \mathrm{U} / \mathrm{mL})$ (Boehringer Mannheim Corp.) was added in the same buffer and incubated for $2 \mathrm{~h}$. This was then removed by aspiration and the slides were washed four times with Buffer 1 at $25^{\circ} \mathrm{C}$. Biotinyl tyramine $(0.007 \mathrm{mM})$ plus $0.003 \% \mathrm{H}_{2} \mathrm{O}_{2}$ in Buffer 1 was added and the sections were incubated for a further $7 \mathrm{~min}$ followed by addition of avidin-biotin-peroxidase (ABC-HRP) (Vector Labs, Burlingame, CA, U.S.A.) and incubation for $30 \mathrm{~min}$ at $25^{\circ} \mathrm{C}$. Sections were then washed and detection performed in substrate solution $\left(0.05 \% 3^{\prime}-3\right.$ diaminobenzidine, $0.003 \% \mathrm{H}_{2} \mathrm{O}_{2}$ in $0.1 \mathrm{M}$ sodium acetate, $\mathrm{pH}$ 6.0), which was applied for $5 \mathrm{~min}$ to allow signal detection. Following detection, sections were stained with hematoxylin and cover-slipped.

Immunocytochemistry. To allow direct comparisons, DEXtreated and untreated tissues were processed on the same slide as previously described (15). Sections $(4 \mu \mathrm{m})$ were deparaffinized in xylene and hydrated in descending ethanol concentrations to distilled water. Antigen retrieval was performed by incubating slides in $0.1 \mathrm{M}$ citric acid, $\mathrm{pH} 8.0$, for $10 \mathrm{~min}$ at $100^{\circ} \mathrm{C}$, followed by cooling to $25^{\circ} \mathrm{C}$, and washing three times in distilled $\mathrm{H}_{2} \mathrm{O}$. Endogenous peroxidase activity was quenched in $3 \% \mathrm{H}_{2} \mathrm{O}_{2}$ in $60 \%$ methanol for $15 \mathrm{~min}$, followed by three washes of distilled water. Blocking solution $(1 \%$ $\mathrm{wt} / \mathrm{vol}$ BSA in TBS [0.05 M Tris-HCL, $0.138 \mathrm{M} \mathrm{NaCl}, 0.0027$ $\mathrm{M} \mathrm{KCl}, \mathrm{pH}$ 8.0]) was applied for $1 \mathrm{~h}$ at $25^{\circ} \mathrm{C}$, followed by incubation with one of three antibodies, mouse anti-PCNA 
(Boehringer Mannheim Corp.), rabbit anti-human IGF-I (a gift from Dr. Louis Underwood, University of North Carolina at Chapel Hill) (16), or rabbit anti-human IGF-II, (a gift from Dr. Marsha Davenport, University of North Carolina at Chapel Hill) (17) for 16 to $18 \mathrm{~h}$ at $4^{\circ} \mathrm{C}$ in a humidified chamber. The primary antibody solution was aspirated, and the slides were washed three times at $25^{\circ} \mathrm{C}$ in TBS. Biotinylated anti-mouse antibody (Vector Labs) or biotinylated anti-rabbit antibody (Jackson Labs, West Grove, PA, U.S.A.) was prepared per the manufacturer's instructions and applied for $60 \mathrm{~min}$ at $25^{\circ} \mathrm{C}$, followed by three TBS washes as above. ABC-HRP (Vector Labs) was prepared according to the manufacturer's instructions, applied for $30 \mathrm{~min}$, and then washed as above. The peroxidase substrate solution was then applied to each section for $5 \mathrm{~min}$. The reaction was terminated by aspiration of the substrate solution followed by washing for $10 \mathrm{~min}$ in distilled water at $25^{\circ} \mathrm{C}$. The sections were counterstained with hematoxylin, dehydrated, and cover-slipped.

TUNEL analyses. Evidence of apoptosis in rat ileum from the different groups were examined using a commercially available kit for the TUNEL method (Apotag; Oncor, Gaithersburg, MD, U.S.A.) (18). Tissue sections were deparaffinized in two changes of xylene for $5 \mathrm{~min}$ each change, followed by two washes in absolute ethanol for $5 \mathrm{~min}$ each wash, one wash in $95 \%$ ethanol for $3 \mathrm{~min}$, one wash in $70 \%$ ethanol for $3 \mathrm{~min}$, and a final wash for $5 \mathrm{~min}$ in PBS. Tissue sections were then digested with proteinase $\mathrm{K}(20 \mu \mathrm{g} / \mathrm{mL})$ for $5 \mathrm{~min}$ at $37^{\circ} \mathrm{C}$ followed by five washes in distilled water for $2 \mathrm{~min}$ each. Sections were equilibrated in a solution of $30 \mathrm{mM}$ Trizma base, pH 7.2, $140 \mathrm{mM}$ sodium cacodylate, and1 mM cobalt chloride (TCC) and then with TCC containing biotin-dUTP, -dATP, and terminal transferase according to the manufacturer's instructions (Roche Biochemical, Indianapolis, IN, U.S.A.) and incubated for $45 \mathrm{~min}$ at $37^{\circ} \mathrm{C}$. The reaction was stopped by adding STOP Buffer $(300 \mathrm{mM}$ sodium chloride, $30 \mathrm{mM}$ sodium citrate) and incubated for $30 \mathrm{~min}$ at $37^{\circ} \mathrm{C}$. Five 3-min washes with PBS were performed for each slide, then detection was performed using the ABC-HRP method described above.

Statistical analyses. All morphologic comparisons were made between the control and treated groups on d 3 of life using a two-tailed $t$ test. Statistical comparisons of morphologic differences between treatment groups from $\mathrm{d} 1$ or 2 were not performed because of their smaller sample sizes. Significance was determined when differences yielded $p$ values $<$ 0.05 .

\section{RESULTS}

Survival and growth of the study animals. Daily i.p. injections were comparably tolerated between DEX-treated and untreated litters. From seven litters $(n=57)$, individual mice were lost in a sporadic manner from both DEX-treated and untreated litters. These deaths were presumed to be a combination of normal attrition and episodic complications of i.p. injection, based on our observation that the surviving littermates appeared healthy upon day-to-day inspection. Of the surviving pups, both DEX-treated $(n=18)$ and saline-treated animals $(n=20)$ showed comparable weight gain during the first $2 \mathrm{~d}$ of the study period (Fig. 1). By d 3, a trend toward reduced weight gain was noted with DEX suggesting that significant growth delay, as occurs with lengthier intervals of DEX exposure (19), would have been evident with a longer growth period. By visual inspection at the time of sacrifice, the bowel and peritoneum appeared normal in all surviving pups regardless of treatment.

DEX administration alters ileal morphology. Histologic examination of ileal cross-sections demonstrated dramatic mucosal change in DEX-treated animals (Fig. 2). At 3 d, DEX treatment resulted in a $42 \%$ increase in goblet cell number (Table 1) and a $64 \%$ increase in total number of mucosal nuclei. In contrast to the demonstrated mucosal enhancement, the surrounding smooth muscle layer displayed a very different response to DEX treatment. There was a $34 \%$ increase in the circumference of the muscularis layer but the total number of circumferential smooth muscle nuclei was unchanged (evident in Fig. 2, and tabulated in Table 1). Taken together, these findings suggest that the circumferential smooth muscle is stretching to accommodate an increased lumen diameter.

DEX administration decreases proliferating cell populations in the muscularis. PCNA immunodetection was used to identify proliferating cell populations in d 3 ileum (Fig. 3). PCNA was easily detected in the crypt epithelium as expected, but only occasional PCNA positive cells were found in other cell populations of the ileum. DEX administration was associated with a significant decrease in the number of PCNApositive nuclei within the circumferential smooth muscle (Table 1). In contrast, the number of PCNA-positive nuclei with the mucosa was similar between treatment groups (Table 1).

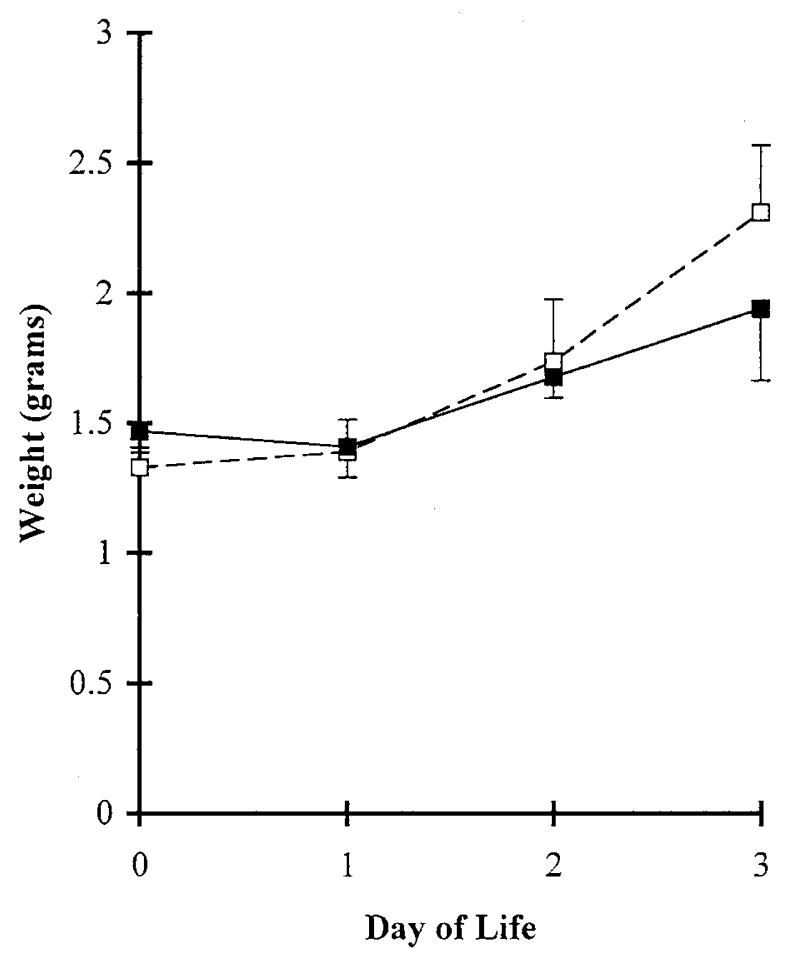

Figure 1. Graph of daily weights in DEX-treated and untreated mouse pups. Open squares represent untreated pups and closed squares represent DEXtreated pups. Error bars represent SD. 

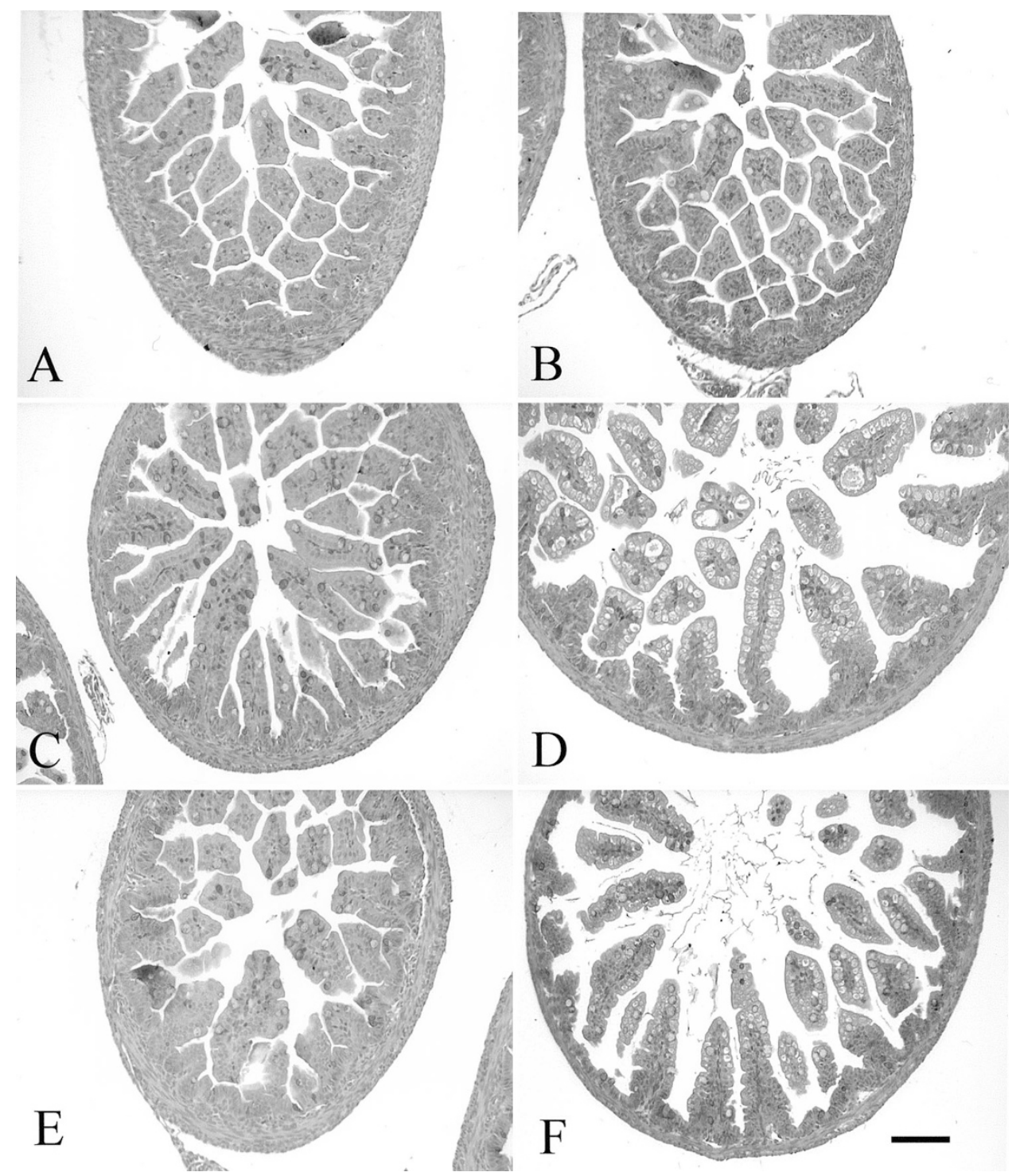

Figure 2. Newborn mice received daily i.p. injections of either DEX $(B, D$, and $F)$ or vehicle $(A, C$, and $E)$. Animals were killed on d $1(A, B), 2(C, D)$, or $3(E, F)$ and their ileums harvested for histologic comparison. The hematoxylin- and eosin-stained examples are shown in black and white. Differences in the architecture of the villi, the contents of the mucosa, and the circumference of the ileal wall are evident between controls and DEX-treated mice after $2 \mathrm{~d}$ of treatment. Magnification $=10 \times$ and bar $=100 \mu \mathrm{m}$.

DEX administration does not reduce apoptosis in newborn ileum. There were only rare TUNEL-positive cells found in the mucosal epithelium and no TUNEL-positive cells were identified in the submucosa and muscular layers in ileal crosssections from d 3 animals, regardless of treatment group (Table 1). There was a small but significant increase in the number of TUNEL-positive nuclei within the mucosa of DEX-treated animals (Table 1).

DEX administration does not alter the sites of IGF expression in the ileum. IGF-I transcripts were localized by in situ hybridization in ileum from d $1-3$ (d 3 is shown in Fig. 4). Localization of transcript was seen in the epithelium, mesenchyme, submucosa, and circumferential muscle, with the most intense signal localized to the crypt epithelium. DEX treatment did not alter the distribution of IGF-I transcripts, although signal was more easily detected in the DEX treatment group.

Dexamethasone alters the pattern of IGF-I localization in the ileum. In ileum of control mice from d 1-3, IGF-I was easily detectable and immunolocalized to the lamina propria, the submucosal layer, the subserosal stroma, and the basolateral margins of the epithelia (Fig. 4). Likewise, there was little IGF-I staining apparent within the muscularis externa although localization was present at the interior margin. Following DEX treatment, a shift in sites of IGF-I immunolocalization was observed with readily detectable. IGF-I was localized within the epithelium of the distal half of the villus on $\mathrm{d} 2$ and 3 of DEX exposure (Fig. 4), but there was minimal or no detection of IGF-I within the cytoplasmic space of control epithelia. In contrast, IGF-II immunohistochemistry resulted in minimal detection within ileum from any of the $3 \mathrm{~d}$ examined. There was no difference in IGF-II distribution between control and DEX-treated ileum but a small amount of punctate, perinuclear IGF-II localization was consistently seen within crypt epithelia in both treatment conditions. This staining pattern was not seen when primary antibody was omitted from the detection assay. Neither IGF-I nor IGF-II immunolocalized to goblet cells. 


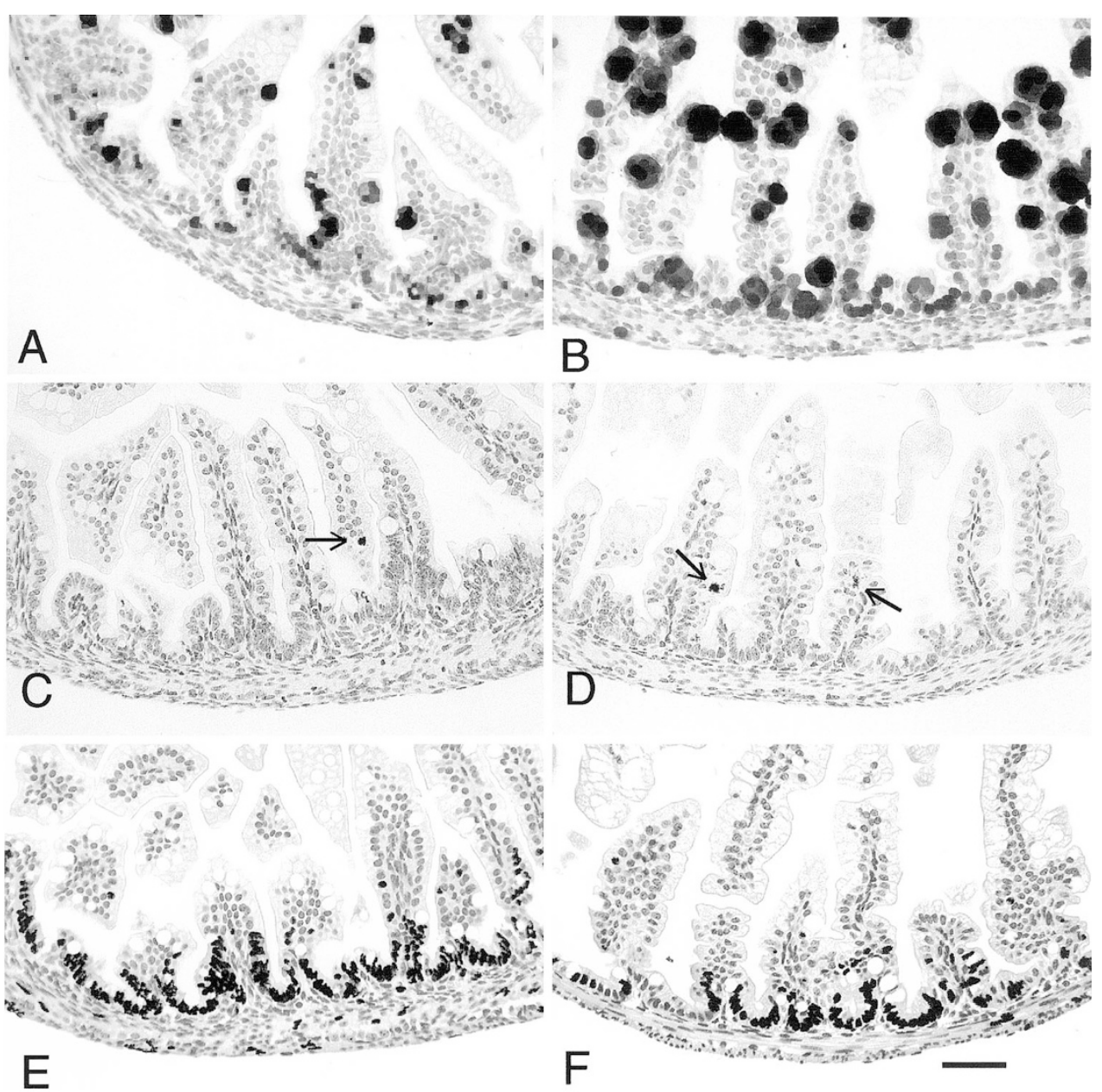

Figure 3. A black-and-white histologic comparison of Alcian blue-stained mucin-containing cells $(A, B)$, TUNEL-labeled apoptotic bodies $(C, D)$, and PCNA-labeled nuclei $(E, F)$ in ileum from control $(A, C$, and $E)$ and DEX-treated $(B, D$, and $F)$ mice who were killed on d 3 of life. The Alcian blue coloring and the HRP coloring of PCNA and TUNEL: have been tagged and digitally converted to black using Adobe Photoshop (Adobe Systems Inc., San Jose, CA, U.S.A.). The arrows point to apoptotic bodies for clarification. Magnification $=20 \times$, bar $=50 \mu \mathrm{m}$.

Table 1. Morphological comparisons between control and dexamethasone (DEX) treated ileum from 3-day-old mouse pups

\begin{tabular}{lcccc}
\hline & Control & $\mathrm{n}$ & DEX-treated & $\mathrm{n}$ \\
\hline Mucosa & & & & \\
$\quad$ No. of goblet cells/section & $194 \pm 41$ & 7 & $279 \pm 79^{*}$ & 7 \\
Total \# of nuclei/section & $1751 \pm 356$ & 7 & $2879 \pm 325^{* *}$ & 6 \\
$\quad$ No. of PCNA positive nuclei/section & $545 \pm 171$ & 7 & $631 \pm 228$ & 6 \\
$\quad$ No. of TUNEL positive nuclei/section & $4.3 \pm 1.8$ & 7 & $11.0 \pm 5.8^{*}$ & 6 \\
Muscularis & & & & \\
Circumference ( $\mu \mathrm{m})$ & $2592 \pm 192$ & 7 & $3470 \pm 373^{* *}$ & 9 \\
Total \# of nuclei/section & $394 \pm 50$ & 7 & $397 \pm 56$ & 9 \\
No. of PCNA positive nuclei/section & $98 \pm 32$ & 7 & $61 \pm 29^{*}$ & 6 \\
No. of TUNEL positive nuclei/section & $0 \pm 0$ & 7 & $0 \pm 0$ & 6 \\
\hline
\end{tabular}

Values are shown with standard deviation, $* p<0.05$, ** $p<0.01$.

\section{DISCUSSION}

The IGFs are known to participate in both cell proliferation and differentiation, acting largely through autocrine/paracrine mechanisms. IGFs are regulated directly via complex transcriptional and translational mechanisms and indirectly through a number of mechanisms that modulate the bioavailability and distribution of these small, secreted peptides (1).
Although changes in the IGF system have been associated with bowel development, inflammatory bowel disease, and repair after bowel injury (3), the role of IGF in small bowel maturation have not been fully defined. Likewise, the effects of glucocorticoids on the IGF system also remain unclear. A number of studies have demonstrated glucocorticoid-mediated changes within the IGF systems of various cell types, including lung fibroblasts (20), lung epithelia (20), osteoblasts (21), and neurons (22), but these changes are diverse and appear to be tissue specific.

In this study, we have focused on the early events following DEX administration in the ileum of newborn mice. DEX alters mucosal morphology by increasing the total number of mucosal cells as well as the specific subset of goblet cells. These findings are consistent with earlier studies (4-8). We have also demonstrated that DEX reduces IGF-I localization within the lamina propria and the extracellular space beneath the epithelia but concomitantly increases IGF-I abundance in the region of the villus tips. This change in peptide location occurs without apparent change in IGF-I transcript localization, which appears abundant in the epithelia of the developing ileum. Because IGF-I is abundant in mammalian breast milk, the DEX- 

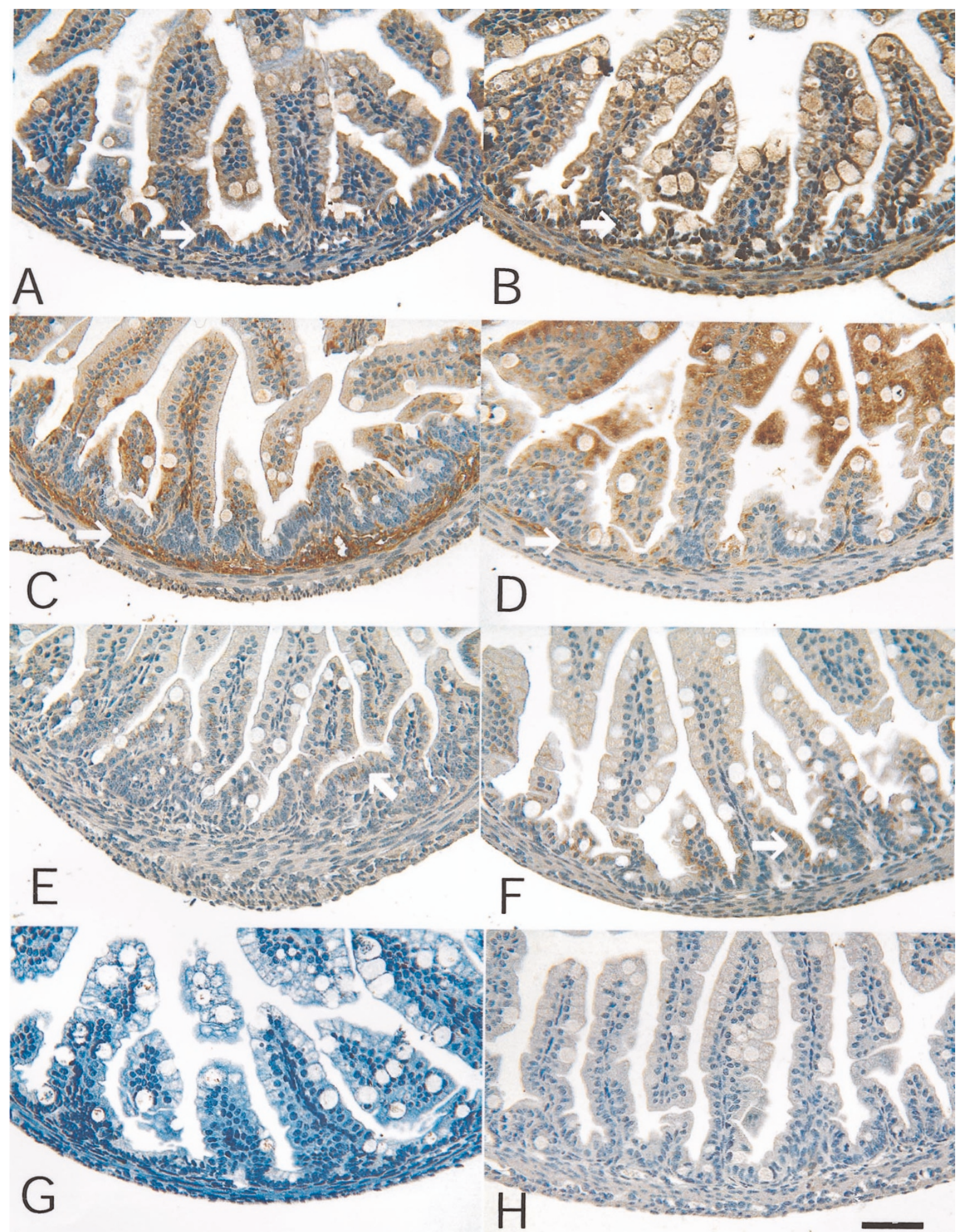

Figure 4. In situ hybridization analysis of IGF-I transcript and immunolocalization analyses of IGF-I and -II in DEX-treated $(B, D, F-H)$ and control ileum $(A$, $C, E$ ). Mice were killed on $\mathrm{d} 3$ of life and the ileum from each mouse was harvested and fixed. The resulting tissues were used for in situ hybridization of IGF-I $(A, B)$ and also for immunolocalization of IGF-I $(C, D)$ and IGF-II $(E, F)$. IGF-I mRNA is localized throughout the tissues in both control and DEX-treated ileum but is most prominent in the crypt epithelia (arrows in $A$ and $B$ ). IGF-I peptide was localized to the connective tissue of the bowel wall in control tissue (arrow in $C$ ) but was diminished in the bowel wall of DEX-treated tissues (arrow in $D$ ). In contrast, IGF-I immunolocalization was dramatically increased in the mucosa at the villus tips $(C v S D)$. IGF-II peptide localization was scant in both treatment conditions $(E, F)$. However, punctate perinuclear localization was uniformly present in the crypt epithelia in both treatment conditions (arrows point to crypt epithelial localization in $E$ and $F$ ). Specificity controls included in situ hybridization with the riboprobe omitted $(G)$, and immunolocalization with primary antibody omitted $(H)$. Magnification $=20 \times$, bar $=50 \mu \mathrm{m}$. 
associated localization of IGF-I in the villus tips may represent increased uptake of IGF-I from the bowel lumen. Previous studies have demonstrated the precocious induction of transport mechanisms with DEX administration (4-8). Future investigations using mice fed formula with or without IGF-I may allow us to determine whether the IGF-I that accumulates in ileal epithelia of DEX-treated mice is of external origin. Whether the concomitant loss of IGF-I from the lamina propria represents DEX-induced catabolism or translocation of the existing IGF-I peptide pool is unknown.

The DEX-associated increase in mucosal cell number could theoretically be consistent with either increased cell proliferation or reduced cell loss. However, since there was not a significant difference in the number of PCNA-positive mucosal cells between treatment groups, it is unlikely that DEX administration enhances mucosal growth through proliferation. There are two potential mechanisms controlling epithelial cell turnover within the small intestine: sporadic apoptosis of enterocytes along the length of the villus and cell shedding at the villus tips. We investigated the possible contribution of apoptosis by using TUNEL labeling. Interestingly, these experiments showed a small but significant increase in the number of apoptotic bodies within DEX-treated mucosa. If cell division is static and apoptosis is slightly increased, then mucosal cells must be accumulating through a reduction in cell shedding at the villus tips.

The epithelial cells within rodent gut mucosa can transit from the crypts to the villus tips in as little as $2 \mathrm{~d}$ (23-25). Within our 72- h time frame, an abrupt reduction in the rate of cell shedding could explain our observed increase in mucosal nuclei with DEX treatment. Our observation that DEX administration to newborn mice is associated with redistribution of IGF-I to the villus tip, the principle site of cell shedding, further implicates IGF-I as a regulator of this process. Many experimental models have demonstrated enhanced mucosal growth with either steroid or IGF-I exposure (2-8, 26-30). The mechanisms by which IGF-I influences cell survival are not fully understood but there are numerous examples where IGF-I exposure prolongs cell viability, particularly in settings favorable to programmed cell death (reviewed in 31, 32). Cell shedding is an intestinal-specific form of cell turnover that has not received the same degree of investigational scrutiny as apoptosis. Additional investigation is needed to elucidate the role of IGF-I as a potential regulator of the different modes of cell turnover within intestinal epithelia.

In contrast to the mucosa, the circumferential smooth muscle shows a very different response to DEX. Although IGF-I is abundant in the bowel wall mesenchyme of control ileum, it wanes dramatically by $72 \mathrm{~h}$ of DEX treatment. Temporally associated with this decrease in IGF-I, the circumferential smooth muscle must accommodate an expanding diameter by increasing in circumference. In general, the response of smooth muscle to stretch is one of rapid cell proliferation (33). IGF-I is thought to be an active participant in this proliferative response and IGF-I overexpression is known to result in smooth muscle hypertrophy (33-37). In our model, the total number of circumferential muscle nuclei was not different between treatment groups whereas the number of PCNA- positive smooth muscle nuclei were actually decreased in DEX-treated animals when compared with controls. This paucity of proliferation is coincident with a rapid reduction in the local abundance of IGF-I and is consistent with published findings that IGF-I is required for stretch-induced smooth muscle proliferation (33).

In summary, our observations support a central role for IGF-I as a local mediator of the divergent changes that glucocorticoids induce in adjacent tissues of the ileum. The stretching of the smooth muscle appears to be a nonproliferative adaptation to increasing lumen diameter. IGF-I localization parallels this relationship by waning in the bowel wall, where muscle proliferation languishes, and waxing in the mucosa, where somatic growth is enhanced. We speculate that this DEX-induced change mirrors the relationship between focal small bowel perforation and early DEX administration in extremely low birth weight infants $(11,12)$. If short courses of early DEX similarly affect the ileal tissues in premature humans, DEX could predispose the bowel to perforation by thinning the circumferential smooth muscle and making the bowel wall more vulnerable.

Acknowledgments. The authors thank Brian Brighton and Ward Jarvis for their technical assistance, Dr. Kay Lund and Dr. Joe Rutledge for their helpful discussions, and Dr. Billie Moats-Staats for her helpful discussions, reading of the manuscript and suggestions.

\section{REFERENCES}

1. Jones J, Clemmons DR 1995 Insulin-like growth factors and their binding proteins: biologic actions. Endo Rev 16:3-34

2. MacDonald RS 1999 The role of insulin-like growth factors in small intestinal cell growth and development. Horm Metab Res 31:103-113

3. Lund K 1998 IGFs and the digestive tract. In: Rosenfield R, Roberts C (eds) Contemporary Endocrinology: The IGF System. Humana Press, Totowa, NJ, pp $519-544$

4. Simon-Assmann PM, Kedinger M, Grenier JF, Haffen K 1982 Control of brush border enzymes by dexamethasone in the fetal rat intestine cultured in vitro. J Pediatr Gastoenterol Nutr 1:257-65

5. Simon-Assmann PM, Kedinger M, Grenier JF, Haffen K 1984 Organ culture of fetal rat intestine. Effects on brush border enzyme activities of the combined administration of dexamethasone and cyclohexamide or actinomycin D. Enzyme 32:65-72

6. Simon-Assmann PM, Lacroix B, Kedinger M, Haffen K 1986 Maturation of brush border hydrolases in human fetal intestine maintained in organ culture. Early Hum Dev 13:65-74

7. Walsh MJ, LeLeiko NS, Sterling Jr KM 1987 Regulation of types I, III, and IV procollagen mRNA synthesis in glucocorticoid-mediated intestinal development. J Biol Chem 262:10814-10818

8. Beaulieu JF, Calvert R 1985 Influences of dexamethasone on the maturation of fetal mouse intestinal mucosa in organ culture. Comp Biochem Physiol A Mol Integr Physiol 82:91-95

9. Isreal EJ, Schiffrin EJ, Carter EA, Freiberg E, Walker WA 1990 Prevention of necrotizing enterocolitis in the rat with prenatal cortisone. Gastroenterology 99:13331338

10. Halac E, Halac J, Begue EF, Casanas JM, Indiveri DR, Petit JF, Figueroa MJ, Olmas JM, Rodriguez LA, Obregon RJ, Martinez MV Grinblat DA, Vilarrodona HO 1990 Prenatal and postnatal corticosteroids therapy to prevent neonatal necrotizing enterocolitis: a controlled trial. J Pediatr 117:132-138

11. Gordon PV, Rutledge J, Sawin R, Thomas S, Woodrum D 1999 Early postnatal dexamethasone increases the risk of focal small bowel perforation in extremely low birth weight infants. J Perinatal 19:573-577

12. Garland JS, Colleen AP, Pauly TH, Whitehead VL, Brand J, Winston JF, Samuels DP, McAuliffe TL 1999 A three-day course of dexamethasone therapy to prevent chronic lung disease in ventilated neonates: a randomized trial. Pediatrics 104:91-99

13. Moats-Staats BM, Price WA, Xu L, Jarvis W, Stiles AD 1995 Regulation of the insulin-like growth factor system during normal rat lung development. Am J Respir Cell Mol Biol 12:56-64

14. Veness-Meehan KA, Moats-Staats BM, Price WA, Stiles AD 1997 Re-emergence of a fetal pattern of insulin-like growth factor expression during hyperoxic rat lung injury. Am J Respir Cell Mol Biol 16:538-549 
15. Price WA, Moats-Staats BM, D'Ercole AJ, Stiles AD 1995 Insulin-like growth factor I (IGF-I) regulates IGFBP-3 and IGFBP-4 by multiple mechanisms in A549 human adenocarcinoma cells. Am J Respir Cell Mol Biol 13:466-476

16. Furlanetto RW, Underwood LE, Van Wyk JJ, D'Ercole AJ 1977 Estimation of somatomedin-C levels in normals and patients with pituitary disease by radioimmunoassay. J Clin Invest 60:648-657

17. Davenport ML, Svoboda ME, Koerber KL, Van Wyk JJ, Clemmons DR, Underwood LE 1988 Serum concentrations of insulin-like growth factor II are not changed by short term fasting and refeeding. J Clin Endocrinol Metab 67:1231-1236

18. Gavrieli Y, Sherman Y, Ben-Sasson SA 1992 Identification of programmed cell death in situ via specific labeling of DNA fragmentation. J Cell Biol 119:493-501

19. Burrin DG, Wester TJ, Davis TA, Fiorotto ML, Chang X 1999 Dexamethasone inhibits small intestinal growth via increased protein catabolism in neonatal pigs. Am J Physiol 276:E269-E277

20. Price WA, Moats-Staats BM, D'Ercole AJ, Stiles AD 1993 Insulin-like growth factor binding protein production and regulation in fetal rat lung cells. Am J Respir Cell Mol Biol 8:425-432

21. Milne M, Quail JM, Baran T 1998 Dexamethasone stimulates osteogenic differentiation in vertebral and femoral bone marrow cell cultures: comparison of IGF-I gene expression. J Cell Biochem 71:382-391

22. Cheung PT, Wu J, Banach W, Chernausek SD 1994 Glucocorticoid regulation of an insulin-like growth factor-binding protein-4 protease produced by a rat neuronal cell line. Endocrinology 135:1328-1335

23. Pothier P, Calvert R 1990 Migration of fetal intestinal intervillous cells in neonatal mice. Anat Rec 227:199-206

24. Bjerknes M, Cheng H 1985 Mucous cells and cell migration in the mouse duodenal epithelium. Anat Rec 212:69-73

25. Ferraris RP, Villenas SA, Diamond J 1992 Regulation of brush-border enzyme activities and enterocyte migration rates in mouse small intestine. Am J Physiol 262:G1047-G1059

26. Burrin DG, Wester TJ, Davis TA, Amick S, Heath JP 1996 Orally administered IGF-I increases intestinal mucosal growth in formula-fed neonatal pigs. Am J Physiol 270:R1085-R1091

27. Houle VM, Schroeder EA, Olde J, Donovan SM 1997 Small intestinal dissachridase activity and ileal villus height are increased in piglets consuming formula containing recombinant human insulin-like growth factor I. Pediatr Res 42:78-86

28. Ma L, Xu RJ 1997 Oral Insulin-like growth factor-I stimulates intestinal enzyme maturation in newborn rats. Life Sci 61:51-58

29. Steeb C-B, Shoubridge CA, Tivey DR, Read LC 1997 Systemic infusion of IGF-I or LR3IGF-I stimulates visceral organ growth and proliferation of gut tissues in suckling rats Am J Physiol 272:G522-G533

30. Ohneda K, Ulshen MH, Fuller CR, D'Ercole AJ, Lund PK 1997 Enhanced growth of small bowel in transgenic mice expressing human insulin-like growth factor I. Gastroenterology 112:444-454

31. Butt AJ, Firth SM, Baxter RC 1999 The IGF axis and programmed cell death Immunol Cell Biol 77:256-262

32. Isgaard J, Tivesten A 1999 The role of growth hormone and insulin-like growth factor-I in the regulation of apoptosis. Growth Horm IGF Res 9(suppl A):125-128

33. Chen Y, Bornfeldt KE, Arner A, Jennische E, Mamqvist U, Uvelius B 1994 Increase in insulin-like growth factor I in hypertrophying smooth muscle. Am J Physio 266:E224-E229

34. Standley PR, Obards TJ, Martina CL 1999 Cyclic stretch regulates autocrine IGF-I in vascular smooth muscle cells: implications in vascular hyperplasia. Am J Physiol 276:E697-E705

35. Fath KA, Alexander RW, Delafontaine P 1993 Abdominal coarctation increases insulin-like growth factor I mRNA levels in rat aorta. Circ Res 72:271-277

36. Wang J, Niu W, Nikiforov Y, Naito S, Chernausek S, Witte D, LeRoith D, Strauch A Fagin JA 1997 Targeted overexpression of IGF-I evokes distinct patterns of organ remodeling in smooth muscle cell tissue beds of transgenic mice. J Clinic Invest 100:1425-1439

37. Oshiro K, Puir P 1998 Increased insulin-like growth factor-I mRNA expression in pyloric muscle in infantile hypertrophic pyloric stenosis. Pediatr Surg Int 13:253-255 